\title{
Implications of standardization of serum 25-hydroxyvitamin D data for the evaluation of vitamin $D$ status in Germany, including a temporal analysis
}

Martina Rabenberg ${ }^{1 *}$, Christa Scheidt-Nave ${ }^{1}$, Markus A. Busch¹, Michael Thamm¹, Nina Rieckmann², Ramón A. Durazo-Arvizu ${ }^{3}$, Kirsten G. Dowling ${ }^{4}$, Zuzana Škrabáková ${ }^{4}$, Kevin D. Cashman ${ }^{4}$,

Christopher T. Sempos ${ }^{5}$ and Gert B. M. Mensink ${ }^{1}$

\begin{abstract}
Background: Comparability of 25-hydroxyvitamin D (25(OH)D) measurements is hampered by method-related differences in measurement values. International standardization of laboratory assays has been suggested to solve this problem.

Methods: As part of the European Commission-funded project 'Food-based solutions for optimal vitamin D nutrition and health through the life cycle' (ODIN), original measurements of serum 25(OH)D of three German national health surveys conducted between 1998 and 2011 have been standardized retrospectively. In these representative population-based samples including persons aged between 1 and 79 years, the original 25(OH)D values were compared with those after standardization. Mean values and prevalences of vitamin $D$ deficiency, insufficiency, and sufficiency $(25(\mathrm{OH}) \mathrm{D}$ levels $<30,30-<50$, and $>=50 \mathrm{nmol} / \mathrm{l}$, respectively) were calculated by sex and age groups based on original and standardized 25(OH)D data.
\end{abstract}

Results: In comparison to the original 25(OH)D levels, the standardized levels showed higher means overall and in age- and sex-specific analyses. After standardization, the prevalence of vitamin D deficiency was lower in all surveys while the prevalence of vitamin D sufficiency was higher. Nevertheless, even after standardization $\sim 15 \%$ of adults and $12.5 \%$ of children had serum $25(\mathrm{OH}) \mathrm{D}$ levels $<30 \mathrm{nmol} / \mathrm{l}$. Thus, the proportion of deficient vitamin D levels in the German population is still considerable.

Conclusions: The use of standardization of $25(\mathrm{OH}) \mathrm{D}$ levels has a substantial impact on estimates of the vitamin $\mathrm{D}$ status in Germany. Since clinical diagnostic, therapeutic and public health decision-making require valid and comparable data, standardization and calibration of commercial, clinical and research laboratory assays for 25(OH)D measurement should become common practice. Until then, researchers, health practitioners and policy makers should be aware of the peculiarities of the measurement methods when comparing and interpreting 25(OH)D levels.

Keywords: Vitamin D, 25(OH)D, Vitamin D deficiency, Standardization, Comparability, Population survey, Germany

\footnotetext{
* Correspondence: RabenbergM@rki.de

'Department of Epidemiology and Health Monitoring, Robert Koch Institute,

General-Pape-Straße 62-66, 12101 Berlin, Germany

Full list of author information is available at the end of the article
}

(c) The Author(s). 2018 Open Access This article is distributed under the terms of the Creative Commons Attribution 4.0 International License (http://creativecommons.org/licenses/by/4.0/), which permits unrestricted use, distribution, and reproduction in any medium, provided you give appropriate credit to the original author(s) and the source, provide a link to the Creative Commons license, and indicate if changes were made. The Creative Commons Public Domain Dedication waiver (http://creativecommons.org/publicdomain/zero/1.0/) applies to the data made available in this article, unless otherwise stated. 


\section{Background}

In the last decade, there has been an explosion of research related to, as well as major public interest in, the health impacts of vitamin D. A long-recognized endocrine function of vitamin $\mathrm{D}$ is the regulation of calcium and phosphorus metabolism. As vitamin D plays an important role in the mineralization of bone, it is not surprising that long-term deficiency can lead to metabolic bone disorders, including rickets in children and osteomalacia or osteoporosis in adults [1-5]. In addition, there have been numerous reports of associations between vitamin D status with a wide spectrum of health conditions and diseases beyond bone, including diabetes mellitus, cardiovascular diseases and different types of cancer [2, 6, 7], even though much about the causal pathway(s) involved is still unclear.

To assess vitamin D status, 25(OH)D measured in serum or plasma is an accepted indicator and widely used in both epidemiological research and clinical practice [8]. However, for the measurement of $25(\mathrm{OH}) \mathrm{D}$, different assays are available including competitive binding-protein assays, immunoassays (e.g. chemiluminescent immunoassay [CLIA]), high performance liquid chromatography (HPLC), and liquid chromatography-tandem mass spectrometry (LC-MS/MS), which is currently considered to be more accurate and precise $[9,10]$. Several studies have shown that different laboratory procedures can yield markedly divergent results for the measured 25(OH)D values due to inter- and between-assay variability as well as inter- and between-laboratory discrepancies [11-14]. Those widespread, method-related differences in results of total $25(\mathrm{OH}) \mathrm{D}$ hamper comparability of $25(\mathrm{OH}) \mathrm{D}$ measurements and progress in the field of vitamin D and health. In particular, they confound the comparison of vitamin D status between countries and World regions as well as assessment of temporal changes. Accordingly, there has been efforts in recent times to standardize the measurement of circulating 25(OH)D in both clinical and research laboratories $[15,16]$.

The Vitamin D Standardization Program (VDSP) organized by the Office of Dietary Supplements of the National Institutes of Health, USA, was established in November 2010 to address the issue $[11,15,16]$. The main goal of the VDSP is the promotion of a standardized $25(\mathrm{OH}) \mathrm{D}$ measurement which is accurate and comparable between different time points, laboratories, and laboratory procedures by calibration of commercial, clinical and research laboratory $25(\mathrm{OH}) \mathrm{D}$ assays. A principal objective is the standardization of $25(\mathrm{OH}) \mathrm{D}$ measurement in national health and nutrition surveys by applying VDSP standardization protocols [11]. The VDSP protocols for standardization of serum 25(OH)D data from past surveys have been applied to national surveys in Canada [17], the US [18] and a number of nationally or regionally representative samples in Europe [16, 19]. As part of the European standardization exercises, two German national health surveys ('German Health Interview and Examination Survey for Adults', DEGS1, and 'German Health Interview and Examination Survey for Children and Adolescents', KiGGS) [20-22] were included in the wider collection of 14 European population studies $(n=55,844)$ [23]. However, this exercise only reported data on serum $25(\mathrm{OH}) \mathrm{D}$ on the entire population. While these analyses permit the estimation of standardized 25(OH)D levels and propensities of vitamin $\mathrm{D}$ deficiency in the contributing countries, they, by design, do not provide a deeper insight into potential differences among age-groups within the wider population groups.

In the present work, we used this opportunity to provide a more in-depth analysis of vitamin D status and to compare prevalences of vitamin D deficiency, insufficiency and sufficiency in the German population based on the original measurements with those after standardization from the two surveys but also stratified by age-groups. In addition, we used standardized serum 25(OH)D data from an older German national health survey of adults ('German National Health Interview and Examination Survey 1998, GNHIES98), not previously reported, to undertake a comparison of data from two cross-sectional surveys in Germany over a ten year period. This new data is of special interest for clinical practice and public health policy.

\section{Methods}

\section{Study design and subjects}

GNHIES98, DEGS1, and KiGGS were conducted by the Robert Koch Institute, Berlin. The design and methods have been described in detail elsewhere [24-30]. In brief, the sample design of each survey included two steps. First, geographical sample points were chosen randomly in proportion to the population size of the federal states and communities. In total, 120 sample points for GNHIES98, 180 sample points for DEGS1 and 160 sample points for KiGGS were included. Second, within each sample point persons were randomly selected stratified by age from local population registries.

\section{GNHIES98}

GNHIES98 was conducted from October 1997 to March 1999. It included a nationwide representative population-based sample of adults aged 18-79 years. The response rate was $61.4 \%$ [24, 25]. Overall, 7124 persons participated in GNHIES98. Of these, 4030 persons (2267 women, 1763 men) took part in the German Nutrition Survey 1998, a module of GNHIES98 [26]. The present analysis is restricted to participants of this substudy with valid 25(OH)D data (2211 women; 1706 men).

\section{DEGS1}

DEGS1 was conducted from November 2008 to December 2011. It included a nationwide representative 
population-based sample of adults aged 18-79 years. DEGS1 used a mixed design including both persons who already participated in the GNHIES98 (response rate $62 \%$ ) and participants who were newly recruited by two-stage stratified random sampling (response rate 42\%) [27]. Overall, 7987 adults participated in DEGS1 including 6995 persons with available serum 25(OH)D levels (3635 women; 3360 men).

\section{KiGGS}

KiGGS was conducted from May 2003 to May 2006 and included a nationwide representative population-based sample of children and adolescents aged $0-17$ years. A total of 17,641 children and adolescents participated in KiGGS (response rate 66.6\%) [30]. In the present study, we had to exclude 935 children $<1$ year of age from whom no blood samples were obtained, 2319 children whose parents declined blood draw and 4366 participants whose blood was measured during the first study year before a change in laboratory method. Thus, in KiGGS we examined 10,015 participants with available serum 25(OH)D levels (4907 girls; 5108 boys).

\section{Data collection and laboratory measurement of serum 25-hydroxyvitamin D}

All surveys comprised, among other survey instruments, measurements in blood samples. Venous blood samples were drawn at study centers and immediately processed and separated. Serum samples were aliquoted, stored at $-40{ }^{\circ} \mathrm{C}$ and then transported and analyzed at the central epidemiology laboratory unit at the Robert Koch Institute. Measurement of serum 25(OH)D was carried out using a chemiluminescent immunoassay (CLIA, LIAISON $^{\oplus} 25 \mathrm{OH}$ Vitamin D TOTAL Assay), one of the most commonly used methods in clinical and research laboratories. Details on analyses have been described elsewhere [20-22].

\section{Application of VDSP standardization protocol to existing 25(OH)D levels}

As part of the European Commission-funded project 'Food-based solutions for optimal vitamin D nutrition and health through the life cycle' (ODIN), serum 25(OH)D levels from GNHIES, DEGS1 and KiGGS were retrospectively standardized by applying a VDSP protocol for standardization of existing serum 25(OH)D data [23]. The protocol has been described in detail elsewhere [11]. In brief, this included the $25(\mathrm{OH}) \mathrm{D}$ re-analysis of a subset (GNHIES98 $n=171$; DEGS1 $n=163$; KiGGS $n=160$ ) of bio-banked serum samples (stored at $-40{ }^{\circ} \mathrm{C}$ ) which were identified by dividing the range of the previous CLIA-based serum 25(OH)D measurements from the entire survey sample into quartiles, with each quartile being sampled according to a uniform distribution $[19,31]$. The bio-banked serum samples from each of the studies were analyzed separately by using University College Cork's LC-MS/MS assay, which has been certified by the Centers for Disease Control and Prevention (CDC) as being traceable to the Reference Measurement Procedures (RMP) of the National Institute for Standards and Technology (NIST), Ghent University, and CDC [9, 32-35].

\section{Statistical analyses}

Analyses were performed with SPSS statistical software (version 20.0; SPSS, Chicago, IL, USA), SAS (version 9.4; SAS Institute, Cary, NC, USA) and STATA (version 12; StataCorp LP, College Station, TX, USA). Simple linear, piecewise linear and Deming regression models were used to examine the best-fit relation between serum $25(\mathrm{OH}) \mathrm{D}$ levels derived from CLIA and LC-MS/MS, which is described in detail elsewhere $[16,23]$. The resulting regression equation which provided the best fit was applied to the entire data set from each study to create standardized data sets. Mean values and prevalence estimates of vitamin D deficiency, insufficiency and sufficiency (defined as serum $25(\mathrm{OH}) \mathrm{D}$ levels $<30 \mathrm{nmol} / \mathrm{l}, 30-<50 \mathrm{nmol} / \mathrm{l}$ and $>=50 \mathrm{nmol} / \mathrm{l}$, respectively [3]) were calculated by sex and age groups based on original and standardized 25(OH)D data. For these analyses, a weighting factor was applied which adjusts for different sampling probabilities within the design strata and corrects deviations in the sample from the German population structure (at the time of each particular survey), taking into account age, sex, region, nationality, community type and education. The relation between the original and re-analyzed serum $25(\mathrm{OH}) \mathrm{D}$ values was analyzed using regression models (ordinary least squares, Deming, and piecewise), as described in detail elsewhere [16-19, 23].

\section{Results}

Characteristics of the three study populations, stratified by sex and age group are shown in Table 1. The weighted percentage for sex and age groups reflect the distribution in the German population at time of survey. In GNHIES98, overall, $51.6 \%$ of the study population were women and $48.4 \%$ were men. In DEGS1, $50.2 \%$ of the participants were women, $49.8 \%$ were men. In KiGGS, $48.6 \%$ were girls and $51.4 \%$ were boys.

The coefficients of the regression equations describing the relation between $25(\mathrm{OH}) \mathrm{D}$ in the VDSP identified subsets of serum samples from GNHIES98, DEGS1 and KiGGS, originally measured by CLIA and re-analyzed by LC-MS/MS, is shown in Table 2. For all three study populations, piecewise regression models provided the best fit (Figs. 1, 2, and 3) and the resulting regression equations were applied to the entire data set from each of the respective studies. The change points for the piecewise regression lines were about 73 for GNHIES98, 122 for 
Table 1 Characteristics of the study populations of GNHIES98, DEGS1 and KiGGS,b

\begin{tabular}{|c|c|c|c|c|c|c|c|c|c|c|c|c|c|c|c|c|c|c|c|}
\hline & & \multicolumn{6}{|c|}{ GNHIES98 } & \multicolumn{6}{|c|}{ DEGS1 } & \multicolumn{6}{|c|}{ KiGGS } \\
\hline & & \multicolumn{2}{|c|}{ Women } & \multicolumn{2}{|l|}{ Men } & \multicolumn{2}{|l|}{ Total } & \multicolumn{2}{|c|}{ Women } & \multicolumn{2}{|l|}{ Men } & \multicolumn{2}{|l|}{ Total } & \multicolumn{2}{|l|}{ Girls } & \multicolumn{2}{|l|}{ Boys } & \multicolumn{2}{|l|}{ Total } \\
\hline & & $n$ & $\%$ & $n$ & $\%$ & $n$ & $\%$ & $n$ & $\%$ & $n$ & $\%$ & $n$ & $\%$ & $n$ & $\%$ & $n$ & $\%$ & $n$ & $\%$ \\
\hline \multicolumn{20}{|c|}{ Age group (in years) } \\
\hline Adults & Children & & & & & & & & & & & & & & & & & & \\
\hline $18-29$ & $1-2$ & 440 & 17.1 & 328 & 18.8 & 768 & 17.9 & 534 & 18.4 & 513 & 19.2 & 1047 & 18.8 & 390 & 10.1 & 395 & 10.1 & 785 & 10.1 \\
\hline $30-39$ & $3-6$ & 539 & 20.9 & 399 & 22.8 & 938 & 21.8 & 426 & 14.4 & 403 & 14.9 & 829 & 14.6 & 1050 & 21.9 & 1079 & 21.9 & 2129 & 21.9 \\
\hline $40-49$ & $7-10$ & 425 & 17.5 & 301 & 19.0 & 726 & 18.2 & 683 & 20.9 & 593 & 22.1 & 1276 & 21.5 & 1274 & 22.7 & 1340 & 22.5 & 2614 & 22.6 \\
\hline $50-59$ & $11-13$ & 376 & 16.8 & 312 & 17.5 & 688 & 17.1 & 744 & 18.3 & 636 & 18.4 & 1380 & 18.3 & 981 & 18.1 & 1047 & 17.9 & 2028 & 18.0 \\
\hline $60-69$ & $14-17$ & 287 & 15.3 & 259 & 14.7 & 546 & 15.0 & 709 & 14.4 & 668 & 13.8 & 1377 & 14.1 & 1212 & 27.3 & 1247 & 27.5 & 2459 & 27.4 \\
\hline 70-79 & - & 144 & 12.3 & 107 & 7.3 & 251 & 9.9 & 539 & 13.6 & 547 & 11.6 & 1086 & 12.6 & - & - & - & - & - & - \\
\hline Total & & 2211 & 51.6 & 1706 & 48.4 & 3917 & 100.0 & 3635 & 50.2 & 3360 & 49.8 & 6995 & 100.0 & 4907 & 48.6 & 5108 & 51.4 & 10,015 & 100.0 \\
\hline
\end{tabular}

${ }^{a}$ Results are weighted, except the number of cases

${ }^{b}$ Rounding may result in minor variations in totals and percentages

DEGS1 and 60.5 for KiGGS samples, respectively (Table 2). For the GNHIES98 and KIGGS samples the lines are still rising after these points but less steeper. For DEGS1 it becomes almost flat.

The weighted relative frequencies for serum $25(\mathrm{OH}) \mathrm{D}$ as measured by using the CLIA and after standardization with the regression equations derived from the comparison with LC-MS/MS are shown in Figs. 4, 5, and 6. The distinct peaks are due to the underlying piecewise regression models. In each survey, standardization shifted the distribution of $25(\mathrm{OH}) \mathrm{D}$ to the right.

Moreover, in each survey, mean serum 25(OH)D levels based on the original measurements were lower in comparison to measurements after standardization across all age groups in men and women (Tables 3 and 4) and in girls and boys (Table 5). In GNHIES98, the standardized mean serum 25(OH)D level was $62.0 \mathrm{nmol} / \mathrm{l}(58.9-65.1)$ in women and $60.9 \mathrm{nmol} / \mathrm{l}$ (57.1-64.7) in men (Table 3), whereas the standardized mean serum $25(\mathrm{OH}) \mathrm{D}$ level in DEGS1 was $49.7 \mathrm{nmol} / \mathrm{l}$ (48.2-51.3) among women and $49.3 \mathrm{nmol} / \mathrm{l}$ (47.4-51.2) among men (Table 4). In KiGGS, the standardized mean serum $25(\mathrm{OH}) \mathrm{D}$ level was $53.2 \mathrm{nmol} / \mathrm{l}(51.1-55.3)$ in girls and $53.7 \mathrm{nmol} / \mathrm{l}(51.5-56.0)$ in boys (Table 5).
Following standardization of serum $25(\mathrm{OH}) \mathrm{D}$ data, the estimated prevalence of vitamin $\mathrm{D}$ deficiency (i.e. serum $25(\mathrm{OH}) \mathrm{D}<30 \mathrm{nmol} / \mathrm{l})$ in the population was lowered by half in both DEGS1 (from 30.2 to 15.2\%) and KiGGS (from 27.0 to $12.5 \%$ ) and by one third in GNHIES98 (from 23.7 to $15.5 \%$ ) (Tables 3, 4, and 5 and Fig. 7). In contrast, the estimated prevalence of vitamin D sufficiency (i.e. serum $25(\mathrm{OH}) \mathrm{D}>=50 \mathrm{nmol} / \mathrm{l}$ ) increased after standardization in each of the surveys (Tables 3,4 , and 5 and Fig. 7).

The effects of standardization are somewhat different for specific sex and age groups. Subgroup analyses also clearly show differences between analyses of originally measured and standardized values, especially in the low and high end of the distribution (Tables 3, 4, and 5). This is due to the fact that the CLIA used in GNHIES98 and KiGGS underestimated serum 25(OH)D in the low end of the distribution and overestimated it in the high end whereas the CLIA used in DEGS1, however, underestimated serum $25(\mathrm{OH}) \mathrm{D}$ in both the low and high end of the distribution (Table 6).

In GNHIES98, the proportion of serum 25(OH)D $<30 \mathrm{nmol} / \mathrm{l}$ was higher in women aged 18 to 29 than in men of the same age $(18.7 \%$ vs. $11.9 \%)$, while the

Table 2 Coefficients of the piecewise regression model between 25(OH)D levels derived from CLIA and LC-MS/MS

\begin{tabular}{|c|c|c|c|c|c|c|c|}
\hline \multirow[b]{2}{*}{ Study } & \multicolumn{3}{|c|}{ If Rval ${ }^{\mathrm{a}} \leq$ value } & \multicolumn{3}{|c|}{ If Rval $\geq$ value } & \multirow[b]{2}{*}{$R^{2}$} \\
\hline & Value & Intercept 1 & $x 1^{b}$ & Value & Intercept 2 & $x 2^{b}$ & \\
\hline GNHIES98 & 73.2698 & -0.2256 & 1.2197 & 73.2698 & 49.0336 & 0.5474 & 0.94 \\
\hline DEGS1 & 121.9968 & 14.5310 & 0.7715 & 121.9968 & 102.1919 & 0.0530 & 0.79 \\
\hline KiGGS & 60.5211 & 9.4005 & 1.0225 & 60.5211 & 52.4099 & 0.3119 & 0.81 \\
\hline
\end{tabular}

25(OH)D Serum 25-hydroxyvitamin D, CLIA Chemiluminescent immunoassay, LC-MS/MS Liquid chromatography-tandem mass spectrometry, GNHIES98 German National Health Interview and Examination Survey 1998, DEGS1 German Health Interview and Examination Survey for Adults, KiGGS German Health Interview and Examination Survey for Children and Adolescents

${ }^{a}$ In piecewise regression, the independent variable is partitioned into intervals and a separate line segment is fit to each interval (Rval = change point in serum $25(\mathrm{OH}) \mathrm{D}$ concentration) [23]

${ }^{\mathrm{b}} \mathrm{X} 1, \mathrm{X} 2=$ slopes of the regression lines 


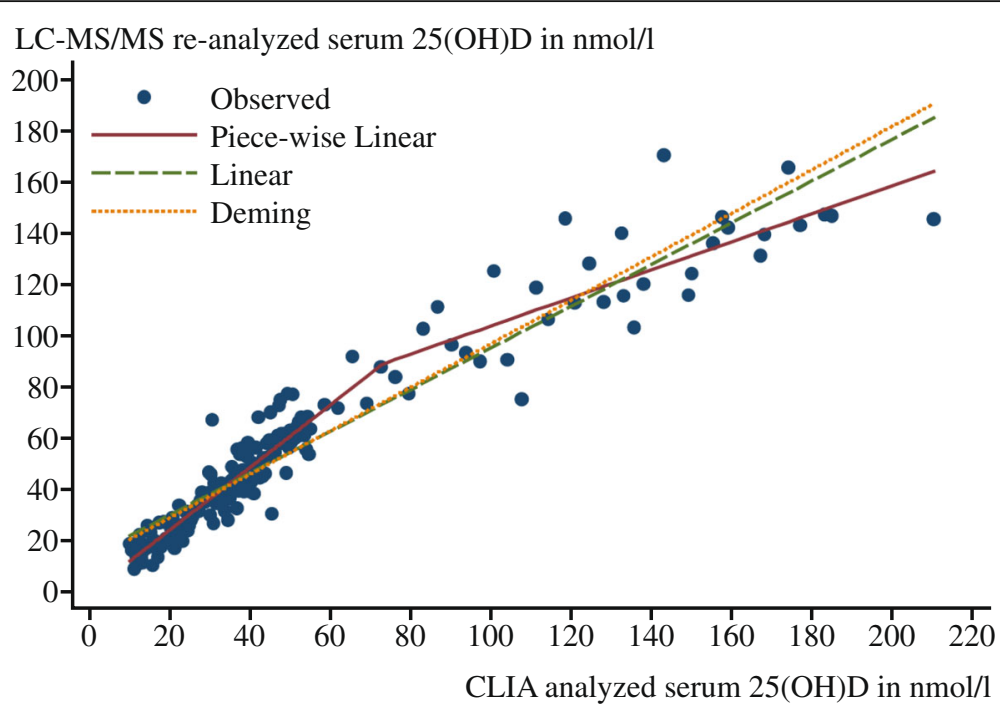

Fig. 1 Calibration study results used to standardize serum samples from GNHIES98. 25(OH)D, Serum 25-hydroxyvitamin D; CLIA, Chemiluminescent immunoassay; LC-MS/MS, Liquid chromatography-tandem mass spectrometry; GNHIES98, German National Health Interview and Examination Survey 1998

proportion of serum $25(\mathrm{OH}) \mathrm{D}>50 \mathrm{nmol} / \mathrm{l}$ was higher in men aged 18 to 29 years than in women of the same age $(68.3 \%$ vs. $57.6 \%)$ (Table 3$)$. However, men aged 60 to 69 years and 70 to 79 years had proportions of serum levels of $25(\mathrm{OH}) \mathrm{D}<30 \mathrm{nmol} / \mathrm{l}$ which were twice as high as those of women of the same age $(60$ to 69 years: $16.9 \%$ vs. $7.3 \%$; 70 to 79 years: $30.2 \%$ vs. $18.5 \%)$. At the other side, the proportion of serum $25(\mathrm{OH}) \mathrm{D}$ levels $>50 \mathrm{nmol} / \mathrm{l}$ was much higher in women aged 60 to 69 years and 70 to 79 years than in men (60 to 69 years: $68.8 \%$ vs. $49.2 \%$; 70 to 79 years: $49.9 \%$ vs. $36.9 \%)$.
In DEGS1, the proportion of standardized serum $25(\mathrm{OH}) \mathrm{D}$ values $<30 \mathrm{nmol} / \mathrm{l}$ was relatively stable across all age groups and sexes, ranging from 13.3 to $19.4 \%$ (Table 4). Only participants aged 60 to 69 showed markedly lower proportions with $9.8 \%$ among women and $9.9 \%$ among men. Women aged 30 to 39 years had a higher proportion of serum $25(\mathrm{OH}) \mathrm{D}$ values $>50 \mathrm{nmol} / \mathrm{l}$ than men of the same age ( $48.3 \%$ vs. $38.4 \%)$, while the opposite was true for the two highest age groups (60 to 69 years: $52.1 \%$ vs. $41.7 \%$; 70 to 79 years: $41.5 \%$ vs. $33.0 \%$ ).

In KiGGS, the prevalence of vitamin $\mathrm{D}$ deficiency increased from young children to teenagers (Table 5). In

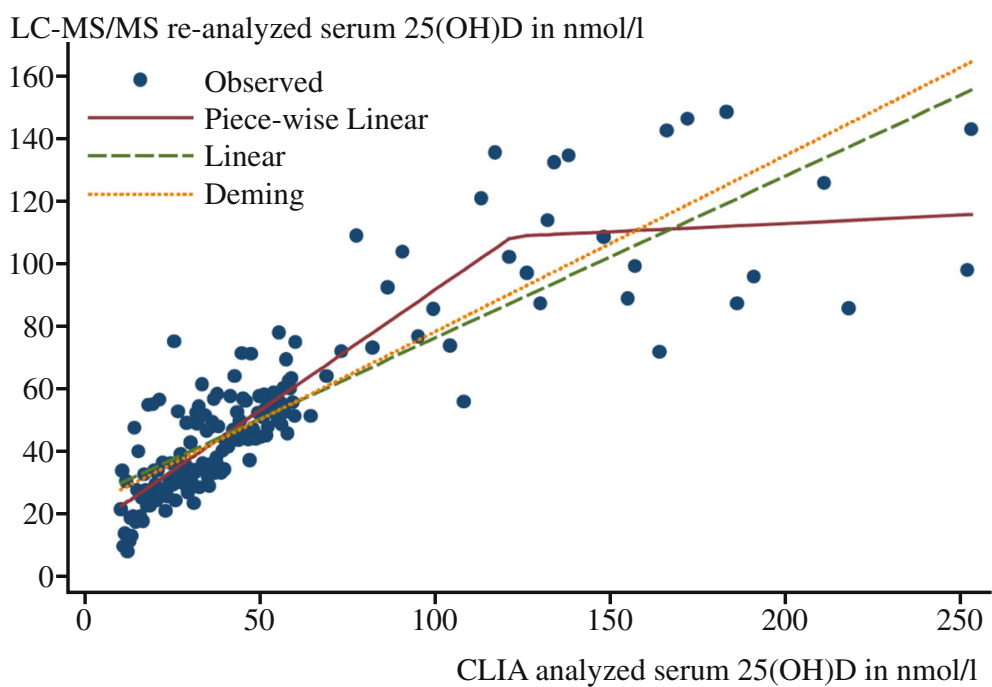

Fig. 2 Calibration study results used to standardize serum samples from DEGS1. 25(OH)D, Serum 25-hydroxyvitamin D; CLIA, Chemiluminescent immunoassay; LC-MS/MS, Liquid chromatography-tandem mass spectrometry; DEGS1, German Health Interview and Examination Survey for Adults 


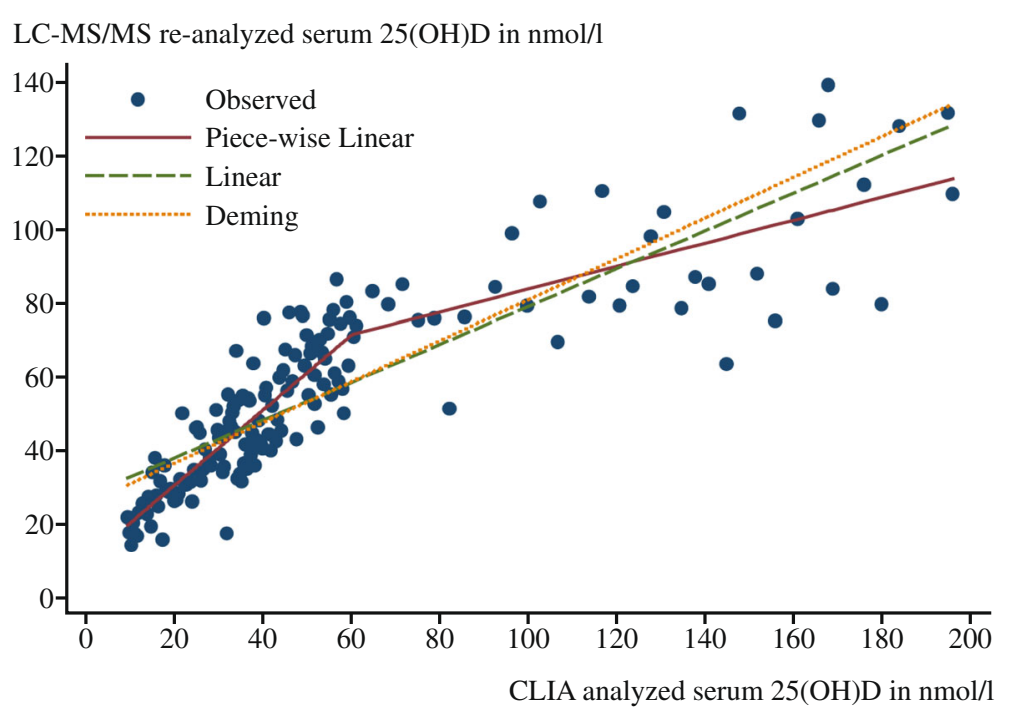

Fig. 3 Calibration study results used to standardize serum samples from KiGGS. 25(OH)D, Serum 25-hydroxyvitamin D; CLIA, Chemiluminescent immunoassay; LC-MS/MS, Liquid chromatography-tandem mass spectrometry; KiGGS, German Health Interview and Examination Survey for Children and Adolescents

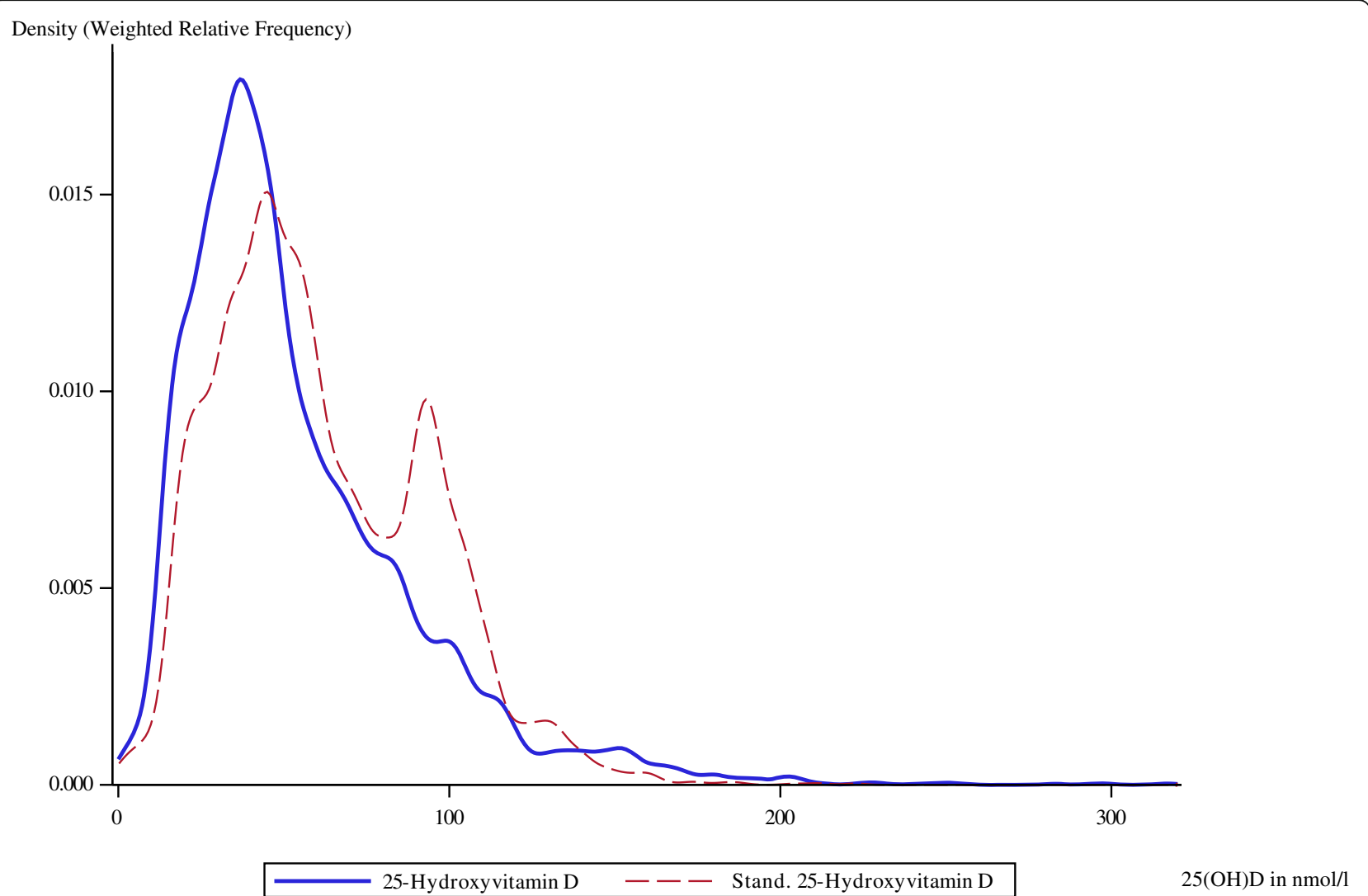

Fig. 4 Weighted relative frequency for original and standardized serum 25(OH)D of GNHIES98 samples. 25(OH)D, Serum 25-hydroxyvitamin D; GNHIES98, German National Health Interview and Examination Survey 1998 


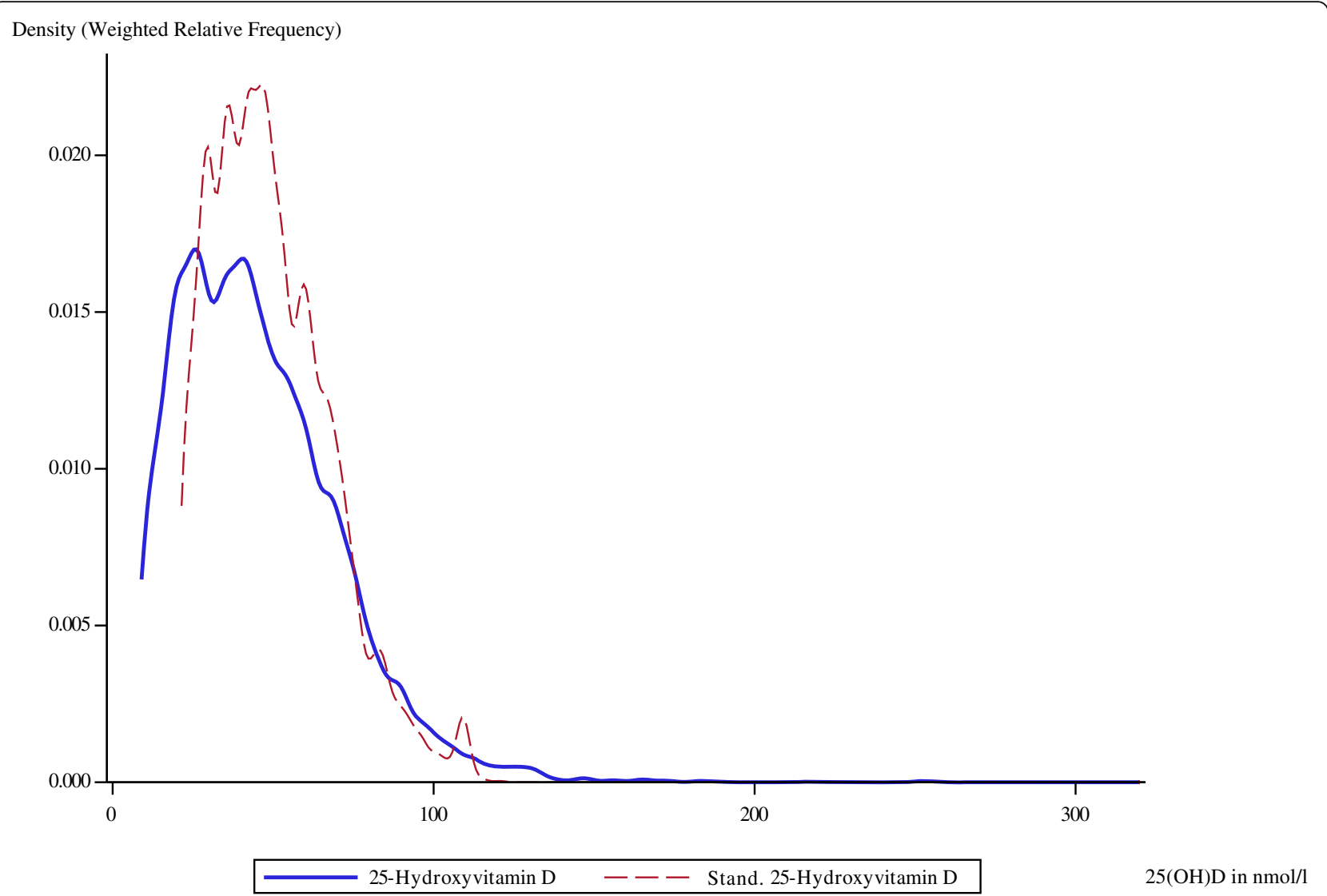

Fig. 5 Weighted relative frequency for original and standardized serum 25(OH)D of DEGS1 samples. 25(OH)D, Serum 25-hydroxyvitamin D; DEGS1, German Health Interview and Examination Survey for Adults

children aged 1 to 2 years, the proportion of serum $25(\mathrm{OH}) \mathrm{D}<30 \mathrm{nmol} / \mathrm{l}$ was about $5 \%$ in both girls and boys and the proportion of serum $25(\mathrm{OH}) \mathrm{D}>50 \mathrm{nmol} / \mathrm{l}$ was about $75 \%$ each. In girls aged 11 to 13 years, however, $18.9 \%$ had $25(\mathrm{OH}) \mathrm{D}$ levels $<30 \mathrm{nmol} / \mathrm{l}$ which was higher than the $11.0 \%$ of boys of the same age (Table 5). In return, boys aged 11 to 13 years had higher proportions of serum 25(OH)D levels $>50 \mathrm{nmol} / \mathrm{l}$ than girls of the same age $(49.8 \%$ vs. $39.6 \%)$. In contrast, in the age group 14 to 17 years, girls had a lower proportion of $25(\mathrm{OH}) \mathrm{D}$ levels $<30 \mathrm{nmol} / \mathrm{l}(13.9 \%)$ than boys of the same age (18.3\%), while boys aged 14 to 17 years had lower proportions of serum 25(OH)D levels $>50 \mathrm{nmol} / \mathrm{l}$ than girls of the same age (44.9\% vs. $54.2 \%)$.

A comparison of the prevalence of vitamin $\mathrm{D}$ deficiency, insufficiency (i.e. serum $25(\mathrm{OH}) \mathrm{D}>30$ but $<50 \mathrm{nmol} / \mathrm{l}$ ) and sufficiency in GNHIES98 and DEGS1 using the standardized serum $25(\mathrm{OH}) \mathrm{D}$ data provides an insight into temporal changes in vitamin D status in the adult German population over a decade. The prevalence of vitamin D deficiency in all adults was very similar in both surveys $(\sim 15 \%)$, but the prevalence of insufficiency was much higher in the more recent DEGS1 survey than GNHIES98 (41\% vs. 27\%, respectively) (Tables 3 and 4). Likewise, the prevalence of sufficiency was lower in DEGS1 than GNHIES98 (44\% vs. 57\%, respectively).

\section{Discussion}

The present work highlights how standardization of $25(\mathrm{OH}) \mathrm{D}$ data has a substantial impact on estimates of the vitamin D status in Germany including higher mean levels, higher prevalence of vitamin D sufficiency and lower prevalence of vitamin D deficiency overall as well as in age- and sex-specific analyses. Although the proportion of persons with deficient $25(\mathrm{OH}) \mathrm{D}$ serum levels is substantially smaller than originally reported, it is still a considerable number of people within the German population. For example, using the prevalences of vitamin $\mathrm{D}$ deficiency based on the new standardized data on serum $25(\mathrm{OH}) \mathrm{D}<30 \mathrm{nmol} / \mathrm{l}$ from DEGS1 and KiGGS, about $15 \%$ of adults and $12.5 \%$ of children were vitamin D deficient which amounts to 11 million persons within the German population. It is also clear from the standardized serum 25(OH)D data from GNHIES98 and DEGS1 in the present work that the prevalence of vitamin D deficiency has remained stable over a ten year period. However, the prevalence of insufficiency $(30-<50 \mathrm{nmol} / \mathrm{l})$ was much 


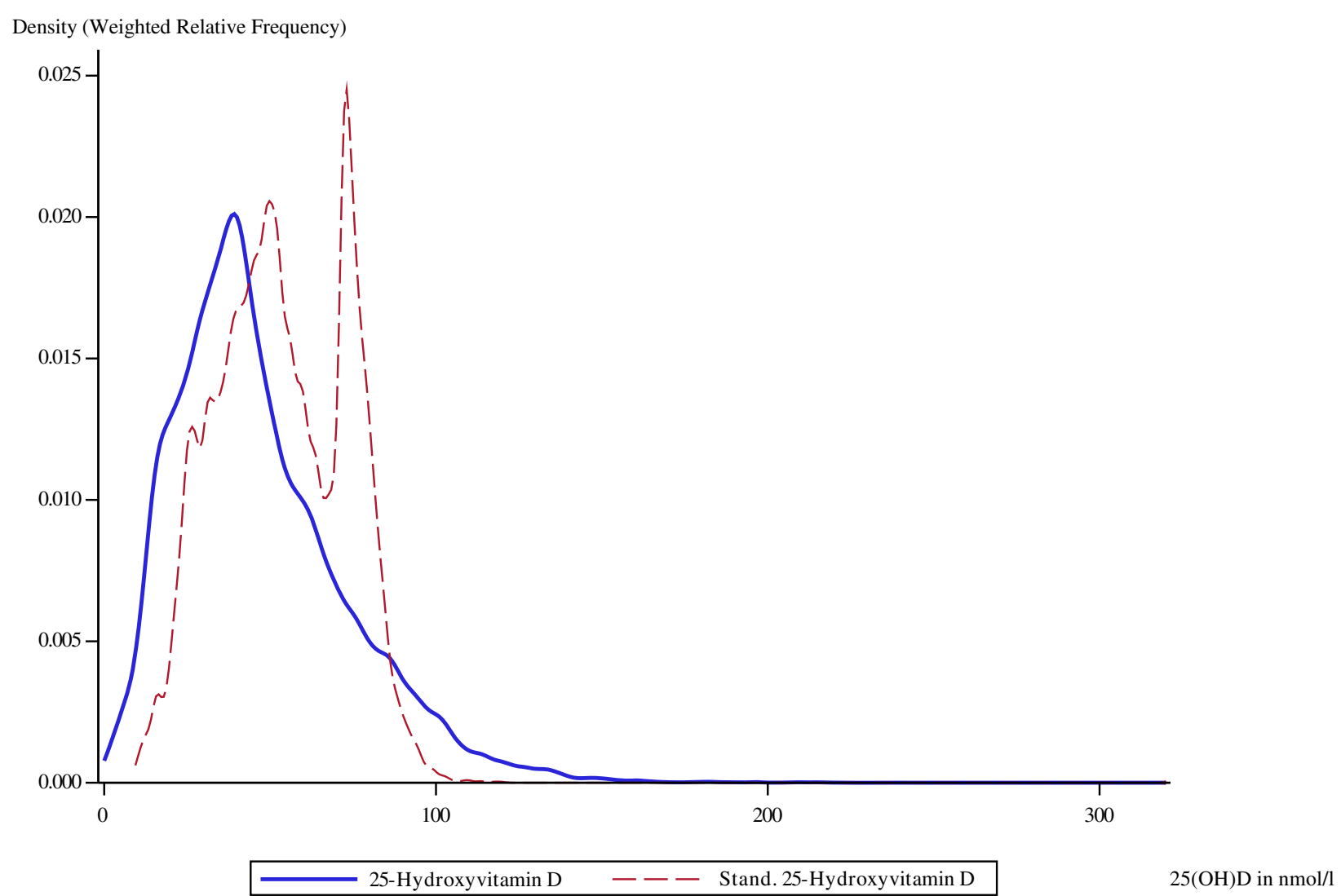

Fig. 6 Weighted relative frequency for original and standardized serum 25(OH)D of KiGGS samples. 25(OH)D, Serum 25-hydroxyvitamin D; KiGGS, German Health Interview and Examination Survey for Children and Adolescents

higher in the more recent DEGS1 survey than GNHIES98 ( $41 \%$ vs. $27 \%$, respectively). The present work did not seek to explore potential underpinning reasons for changes in vitamin D status over time in the German adult population, but this difference may be related to changes in outdoor activity, sun tan behavior or sunscreen use [36].

Within all of the three surveys blood samples were taken on a voluntary base. We assume that this procedure did not cause a systematic selection bias, however, also a weighting factor was used to correct for deviations compared to the population structure at the time of each of the surveys. Within GNHIES98, serum 25(OH)D was measured in a subsample which also participated in a nutrition module. Participation was randomized; however, women of child bearing age were oversampled because of a connected folate study. This deviation in the sample was corrected by using a specific weighting factor.

The new data on three German national health surveys complement and extend data from several surveys either side of the Atlantic that have been standardized according to VDSP protocols in recent years $[16,17,19,23]$. Collectively, all of these exercises clearly show that the originally used assays demonstrate varying precision across the entire measuring range resulting in minor to major differences (both positive and negative) between original and standardized serum $25(\mathrm{OH}) \mathrm{D}$ data. This was even the case for studies using the same kind of assay, e.g. CLIA (the original assay used in the three German surveys), as demonstrated recently in the data from the ODIN project [23]. For example, in an Icelandic cohort study including 5519 adults with mean age of 77 years, the prevalence of serum $25(\mathrm{OH}) \mathrm{D}$ level $<30 \mathrm{nmol} / \mathrm{l}$ (indicating deficiency) was lower at $8.4 \%$ after standardization compared to the original estimate of $17.2 \%$. In a population-based survey conducted in the UK with 977 participants aged $>=19$ years, prevalence of deficiency was about a fifth lower after standardization (30.7\% vs. $24.0 \%)$. However, in a Dutch cohort study including 915 women aged $>=55$ years prevalence estimates for serum $25(\mathrm{OH}) \mathrm{D}$ levels $<30 \mathrm{nmol} / \mathrm{l}$ were slightly higher after standardization ( $3.8 \%$ vs. $4.6 \%)$.

Likewise, divergent results in terms of the impact of standardization have also been reported in surveys for children and adolescents, which have used the CLIA [23]. Baseline serum 25(OH)D data from a cross-over trial conducted in Denmark including 779 children aged 8-11 years, for example, found a higher prevalence of $25(\mathrm{OH}) \mathrm{D}$ levels $<30 \mathrm{nmol} / \mathrm{l}$ (6.2\% compared to $5.0 \%)$, whereas a population-based survey from the UK with 
Table 3 Means and prevalence of 25(OH)D categories based on original and standardized 25(OH)D levels of GNHIES98 ${ }^{\mathrm{a}}$

\begin{tabular}{|c|c|c|c|c|c|c|c|c|}
\hline & \multirow{2}{*}{\multicolumn{2}{|c|}{ Mean serum 25(OH)D levels }} & \multicolumn{6}{|c|}{ Serum 25(OH)D levels by thresholds of the IOM 2011 in \% } \\
\hline & & & \multicolumn{2}{|l|}{$<30 \mathrm{nmol} / \mathrm{l}$} & \multicolumn{2}{|l|}{$30-<50 \mathrm{nmol} / \mathrm{l}$} & \multicolumn{2}{|l|}{$>=50 \mathrm{nmol} / \mathrm{l}$} \\
\hline & $\overline{\mathrm{O}}$ & d & Original & S & Original & zed & Original & ized \\
\hline & $\mathrm{nmol} / \mathrm{l}(95 \% \mathrm{Cl})$ & $\mathrm{nmol} / \mathrm{l}(95 \% \mathrm{Cl})$ & $\%(95 \% \mathrm{Cl})$ & $\%(95 \% \mathrm{Cl})$ & $\%(95 \% \mathrm{Cl})$ & $\%(95 \% \mathrm{Cl})$ & $\%(95 \% \mathrm{Cl})$ & $\%(95 \% \mathrm{Cl})$ \\
\hline Women & $55.4(51.8-59.0)$ & $62.0(58.9-65.1)$ & $23.8(20.2-27.8)$ & $15.8(12.8-19.3)$ & $34.0(30.8-37.3)$ & $28.0(25.2-30.9)$ & $42.2(38.3-46.2)$ & $56.3(52.3-60.2)$ \\
\hline $18-29$ years & $65.4(59.5-71.4)$ & $70.8(65.7-75.8)$ & $19.5(14.4-25.9)$ & $18.7(12.9-26.2)$ & $26.5(21.8-31.8)$ & $23.7(18.9-29.3)$ & $54.0(47.3-60.5)$ & $57.6(50.3-64.6)$ \\
\hline $30-39$ y & 60.3 & 66.6 & $19.0(15.2-23.4)$ & $14.4(10.6$ & $32.4(28.1-37.0)$ & $26.6(22$. & 48.6 & 58. \\
\hline $40-49$ & $57.5(52.8-62.3)$ & $64.4(60.4-68.4)$ & $21.2(16.6-26.7)$ & $14.9(10.5-20.7)$ & $32.5(27.3-38.2)$ & $30.5(24.8-36.9)$ & $46.3(40.5-52.1)$ & $54.6(46.6-62.4)$ \\
\hline $50-59$ years & $52.9(47.4-58.4)$ & $60.2(55.4-65.1)$ & $24.2(18.8-30.5)$ & $17.8(13.3-23.4)$ & $36.1(30.5-42.1)$ & $27.4(22.1-33.4)$ & $39.7(33.5-46.2)$ & $54.8(47.5-61.9)$ \\
\hline $60-6$ & 4.2) & $56.5(5$ & $26.7(20.1$ & 7.3 & -48.2) & $230 / 183$ & 9.5) & 68.8 \\
\hline 70-79 years & $40.9(35.0-46.9)$ & $.3-54.1)$ & $37.4(27.4-48.7)$ & $.7-29.9)$ & $3.2-48.3)$ & $31.7(21.4-44.1)$ & $24.9(16.3-36.0)$ & $49.9(37.5-62.3)$ \\
\hline Men & $53.4(49.1-57.6)$ & $60.9(57.1-64.7)$ & $23.6(19.8-28.0)$ & $15.1(12.2-18.7)$ & $33.2(29.9-36.5)$ & $26.9(23.7-30.5)$ & $43.2(38.1-48.5)$ & $57.9(52.7-62.9)$ \\
\hline $18-2$ & $52.2(47.5-56.8)$ & $60.1(55.5-64.7)$ & $23.3(16.9-31.1)$ & $11.9(8.4-16.7)$ & $31.4(25.6-37.9)$ & $19.8(15.5-25.0)$ & $45.3(38.0-52.8)$ & $68.3(61.5-74.4)$ \\
\hline 30-39 years & $5.2(50.0-60.3)$ & $62.3(57.8-66.9)$ & $.8-28.9)$ & 11.7 & 33 & ) & 8) & 60.9 \\
\hline 40-49 years & $51.5(44.9-58.1)$ & $59.2(53.2-65.3)$ & $25.4(19.3-32.5)$ & $13.1(9.5-17.9)$ & $34.4(28.0-41.5)$ & $27.7(23.5-32.3)$ & $40.2(32.0-49.1)$ & $59.2(53.8-64.4)$ \\
\hline $50-59 y$ & $49.4(44.4-54.4)$ & $57.1(52.4-61.9)$ & $26.8(21.4-33.1)$ & $16.0(11.7-21.4)$ & $34.7(29.0-40.9)$ & $28.2(22.7-34.4)$ & $38.5(31.3-46.2)$ & $55.8(48.9-6$ \\
\hline $60-69$ years & .5) & .8) & 4) & $-23.8)$ & 9) & .4) & 8.7) & 49 \\
\hline 70-79 years & $51.1(43.3-58.9)$ & $58.4(50.8-66.0)$ & $31.3(21.0-44.0)$ & $30.2(20.3-42.3)$ & $28.2(18.3-40.8)$ & $33.0(24.0-43.5)$ & $40.4(29.2-52.8)$ & $36.9(27.0-47.9)$ \\
\hline otal & $54.4(50.8-58.0)$ & $61.5(58.3-64.7)$ & $23.7(20.3-27.5)$ & $15.5(12.8-18.6)$ & $33.6(31.0-36.3)$ & $27.5(25.1-30.0)$ & $42.7(38.7-46.8)$ & $57.1(53.0-61.1)$ \\
\hline
\end{tabular}

25(OH)D Serum 25-hydroxyvitamin D, GNHIES98 German National Health Interview and Examination Survey 1998, IOM Institute of Medicine, USA, Cl confidence interval

a Results are weighted population estimates

Table 4 Means and prevalence of 25(OH)D categories based on original and standardized 25(OH)D levels of DEGS1 ${ }^{a}$

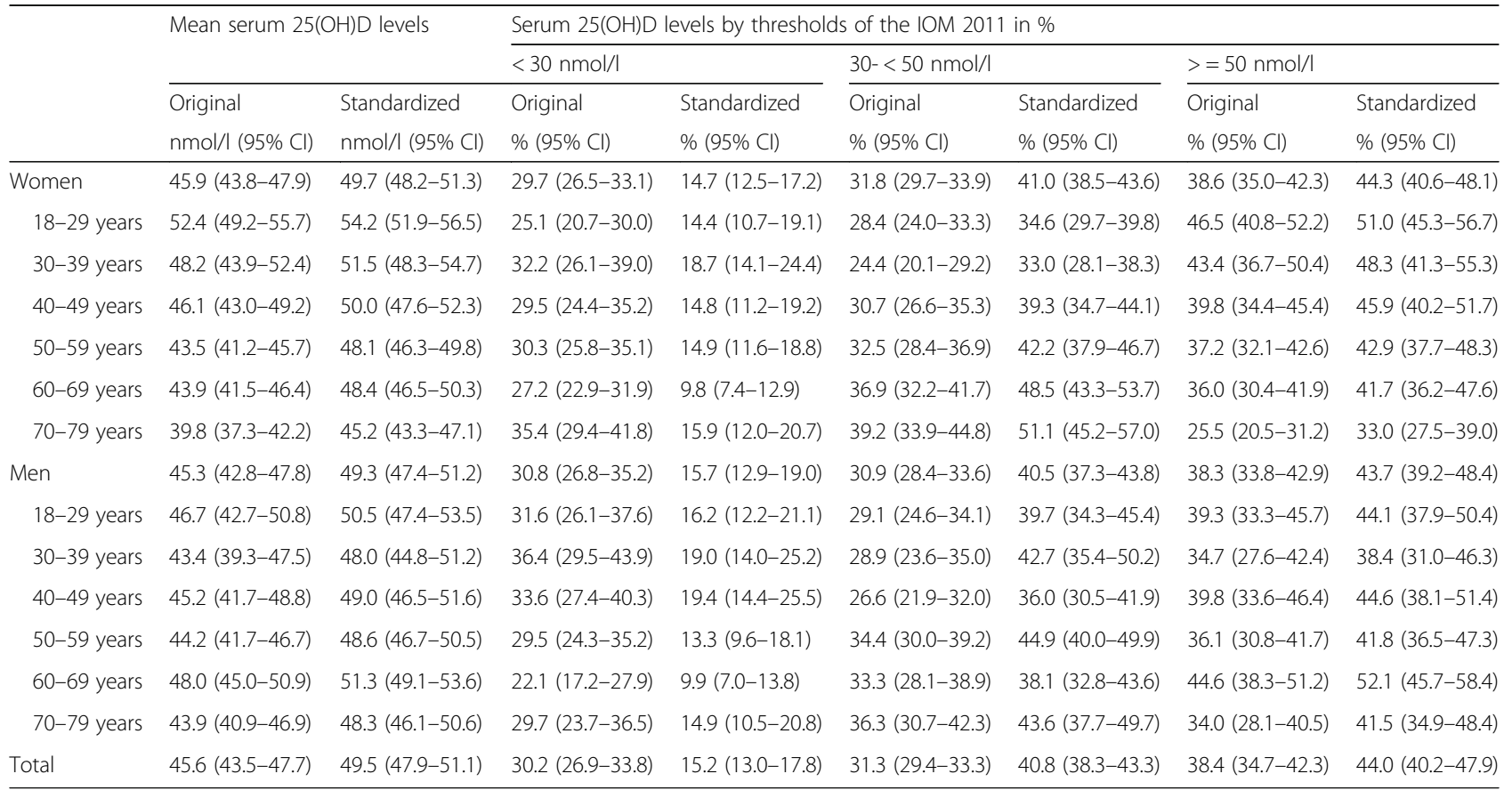

25(OH)D Serum 25-hydroxyvitamin D, DEGS1 German Health Interview and Examination Survey for Adults, IOM Institute of Medicine, USA, Cl

a Results are weighted population estimates 
Table 5 Means and prevalence of 25(OH)D categories based on original and standardized 25(OH)D levels of KiGGS

\begin{tabular}{|c|c|c|c|c|c|c|c|c|}
\hline & \multirow{2}{*}{\multicolumn{2}{|c|}{ Mean serum 25(OH)D levels }} & \multicolumn{6}{|c|}{ Serum 25(OH)D levels by thresholds of the IOM 2011 in \% } \\
\hline & & & \multicolumn{2}{|l|}{$<30 \mathrm{nmol} / \mathrm{l}$} & \multicolumn{2}{|l|}{$30-<50 \mathrm{nmol} / \mathrm{l}$} & \multicolumn{2}{|l|}{$>=50 \mathrm{nmol} / \mathrm{l}$} \\
\hline & Original & Standardized & Original & Standardized & Original & Standardized & Original & Standardized \\
\hline & $\mathrm{nmol} / \mathrm{l}(95 \% \mathrm{Cl})$ & $\mathrm{nmol} / \mathrm{l}(95 \% \mathrm{Cl})$ & $\%(95 \% \mathrm{Cl})$ & $\%(95 \% \mathrm{Cl})$ & $\%(95 \% \mathrm{Cl})$ & $\%(95 \% \mathrm{Cl})$ & $\%(95 \% \mathrm{Cl})$ & $\%(95 \% \mathrm{Cl})$ \\
\hline Girls & $46.7(44.1-49.3)$ & $53.2(51.1-55.3)$ & $27.1(22.9-31.9)$ & $12.5(10.0-15.7)$ & $36.8(34.4-39.2)$ & $33.5(30.3-36.8)$ & $36.1(31.8-40.6)$ & $54.0(48.9-59.0)$ \\
\hline $1-2$ years & $62.1(58.5-65.7)$ & $63.8(61.3-66.3)$ & $14.2(10.4-19.0)$ & $5.7(3.5-9.0)$ & $24.7(19.6-30.6)$ & $19.7(15.2-25.2)$ & $61.1(53.9-67.9)$ & $74.6(68.5-79.9)$ \\
\hline $3-6$ years & $48.8(45.6-52.0)$ & $3(52.9-57.7)$ & $22.2(17.7-27.4)$ & $9.1(6.5-12.6)$ & $38.5(34.9-42.2)$ & $31.8(27.6-36.3)$ & $39.4(33.9-45.1)$ & $59.1(52.9-65.0)$ \\
\hline $7-10$ years & $43.5(40.8-46.3)$ & $51.4(49.1-53.7)$ & $28.3(23.2-34.0)$ & $12.2(9.2-16.1)$ & $40.2(36.4-44.2)$ & $36.7(32.2-41.3)$ & $31.5(26.4-37.1)$ & $51.1(44.9-57.3)$ \\
\hline 1 & в) & ) & 5) & 18 & 6) & 7) & 3) & 39 \\
\hline 14-17 years & $48.0(44.8-51.1)$ & $53.5(51.1-56.0)$ & $29.0(24.1-34.5)$ & $13.9(10.8-17.6)$ & $34.0(30.8-37.3)$ & $32.0(28.4-35.7)$ & $37.0(32.1-42.2)$ & $54.2(48.6-59.7)$ \\
\hline jys & $47.4(44.6-50.2)$ & $53.7(51.5-56.0)$ & $26.9(22.5-31.7)$ & $12.5(9.7-15.8)$ & $35.3(33.1-37.6)$ & $32.7(29.4-36.2)$ & $37.8(33.3-42.6)$ & $54.8(49.4-60.1)$ \\
\hline $1-2$ years & $2(62.2-70.2)$ & 6 & e & 8.2) & 2) & 5) & 66.2 & 79 \\
\hline $3-6$ years & $48.4(44.9-51.8)$ & $54.6(51.9-57.3)$ & $26.4(21.1-32.4)$ & $11.5(8.4-15.5)$ & $32.6(29.0-36.3)$ & $31.5(27.0-36.3)$ & $41.1(35.2-47.2)$ & $57.0(50.4-63.5)$ \\
\hline $7-10$ years & $46.4(43.5-49.4)$ & $53.8(51.4-56.3)$ & $23.8(19.1-29.2)$ & $10.9(8.0-14.6)$ & $39.4(35.9-43.0)$ & $31.6(27.2-36.3)$ & $36.8(31.3-42.7)$ & $57.5(51.1-63.8)$ \\
\hline $11-$ & $-48.5)$ & 52.1 & $1-32.3)$ & $11.0(7$ & $41.9(38.5-45.5)$ & 39.2 & $31.2(26.3-36.5)$ & 49.8 \\
\hline 14-17 years & $42.1(39.1-45.0)$ & $49.4(47.0-51.9)$ & $35.7(30.2-41.6)$ & $18.3(14.4-22.9)$ & $34.3(30.8-38.0)$ & $36.8(33.3-40.4)$ & $30.0(25.5-34.9)$ & $44.9(39.4-50.7)$ \\
\hline Total & $47.1(44.4-49.7)$ & $53.5(51.3-55.6)$ & $27.0(22.8-31.7)$ & $12.5(9.9-15.6)$ & $36.0(34.0-38.1)$ & $33.1(30.0-36.3)$ & $37.0(32.7-41.5)$ & $54.4(49.3-59.5)$ \\
\hline
\end{tabular}

25(OH)D Serum 25-hydroxyvitamin D, KiGGS German Health Interview and Examination Survey for Children and Adolescents, IOM Institute of Medicine, USA, $\mathrm{Cl}$ confidence interval

a Results are weighted population estimates

511 children and adolescents aged 1-18 years described a moderately lower prevalence compared to original values (18.4\% versus $23.3 \%)$.

Besides the well-reported between-laboratory differences even for the same assay [14], these differences may also be linked to methodological issues even within the CLIA assay over time e.g. assay drift/shift or changes in assay composition like reformulation of reagents [37, 38]. It is possible that the process of standardization of the German data may have contributed to the observed differences. First, the storage time of re-analyzed blood samples used for VDSP standardization was relatively long (4-17 years). However,

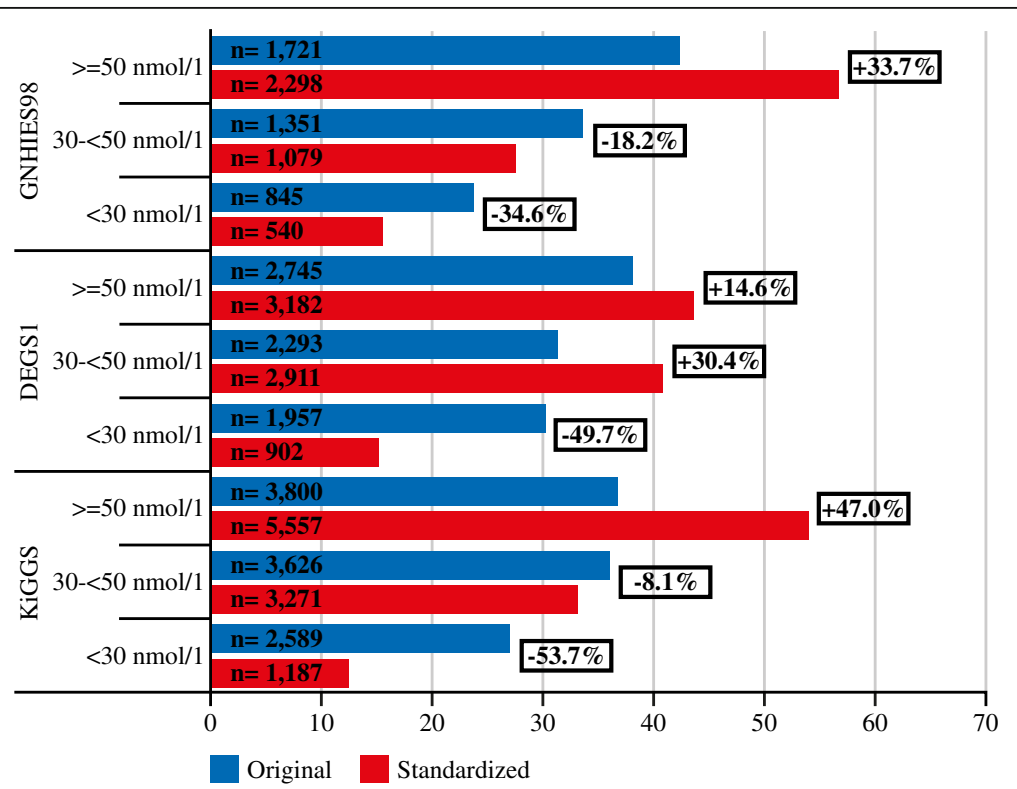

Fig. 7 25(OH)D categories based on original and standardized serum 25(OH)D levels of GNHIES98, DEGS1 and KiGGS. 25(OH)D, Serum 25hydroxyvitamin D; GNHIES98, German National Health Interview and Examination Survey 1998; DEGS1, German Health Interview and Examination Survey for Adults; KiGGS, German Health Interview and Examination Survey for Children and Adolescents 
Table 6 Predicted data shifts from original to standardized 25(OH)D levels for GNHIES98, DEGS1 and KiGGS

\begin{tabular}{|c|c|c|c|c|c|}
\hline \multirow{2}{*}{\multicolumn{2}{|c|}{$\begin{array}{l}\text { GNHIES98 } \\
\text { Serum } 25(\mathrm{OH}) \text { D levels in } \mathrm{nmol} / \mathrm{l}\end{array}$}} & \multirow{2}{*}{\multicolumn{2}{|c|}{$\frac{\text { DEGS1 }}{\text { Serum 25(OH)D levels in } \mathrm{nmol} / \mathrm{l}}$}} & \multirow{2}{*}{\multicolumn{2}{|c|}{$\begin{array}{l}\text { KiGGS } \\
\text { Serum 25(OH)D levels in nmol/l }\end{array}$}} \\
\hline & & & & & \\
\hline Original & Standardized & Original & Standardized & Original & Standardized \\
\hline 1 & 1 & 1 & 15 & 1 & 10 \\
\hline 5 & 6 & 5 & 18 & 5 & 15 \\
\hline 10 & 12 & 10 & 22 & 10 & 20 \\
\hline 15 & 18 & 15 & 26 & 15 & 25 \\
\hline 20 & 24 & 20 & 30 & 20 & 30 \\
\hline 25 & 30 & 25 & 34 & 25 & 35 \\
\hline 30 & 36 & 30 & 38 & 30 & 40 \\
\hline 40 & 49 & 40 & 45 & 40 & 50 \\
\hline 50 & 61 & 50 & 53 & 50 & 61 \\
\hline 60 & 73 & 60 & 61 & 60 & 71 \\
\hline 75 & 91 & 75 & 72 & 75 & 76 \\
\hline 80 & 93 & 80 & 76 & 80 & 77 \\
\hline 90 & 98 & 90 & 84 & 90 & 80 \\
\hline 100 & 104 & 100 & 92 & 100 & 84 \\
\hline 125 & 117 & 125 & 109 & 125 & 91 \\
\hline 150 & 131 & 150 & 110 & 150 & 99 \\
\hline 200 & 159 & 200 & 113 & 200 & 115 \\
\hline 250 & 186 & 250 & 115 & 250 & 130 \\
\hline 300 & 213 & 300 & 118 & 300 & 146 \\
\hline
\end{tabular}

25(OH)D Serum 25-hydroxyvitamin D, GNHIES98 German National Health Interview and Examination Survey 1998, DEGS1 German Health Interview and Examination Survey for Adults, KiGGS German Health Interview and Examination Survey for Children and Adolescents

several studies indicate that serum $25(\mathrm{OH}) \mathrm{D}$ is stable even after long-term storage [39-42]. Moreover, multiple freeze-thaw cycles also seem to have no considerable consequences on serum 25(OH)D [43, 44]. Second, analyses and re-analyses were conducted in different laboratories and as mentioned above, this might have had an effect on differences seen in original and standardized 25(OH)D data. Third, only 160-171 bio-banked blood samples were re-analyzed with LC-MS/MS to develop a calibration equation to predict $25(\mathrm{OH}) \mathrm{D}$ levels for the entire samples of each survey. However, these 160-171 samples were based on power calculations and also were derived from a specific uniform sampling procedure within quartiles which has been shown in simulations to provide for the most efficient coverage of the full distribution of the sample in question. In addition, previous studies showed very good concordance between VDSP protocol predicted 25(OH)D levels and analyses comprising the entire sample [16].

Challenges in the evaluation and comparison of vitamin $\mathrm{D}$ data may also be caused by the fact that there is currently no consensus on optimal levels of serum 25(OH)D [3, 4, 45, 46]. In addition, the most commonly used thresholds to define vitamin D deficiency, insufficiency and sufficiency $(25(\mathrm{OH}) \mathrm{D}$ levels, $<30,30-<50$ and
$>=50 \mathrm{nmol} / \mathrm{l}$, respectively, as suggested by the IOM [3]), are being used irrespective from the assay employed.

According to the wide range of methodological issues, the interpretation of the actual vitamin D status is complicated, especially the diagnosis of vitamin D deficiency. Hence, in clinical settings, the potential misclassification of $25(\mathrm{OH}) \mathrm{D}$ levels may result in over- or undertreatment of patients and difficulties in monitoring supplementation therapy.

Furthermore, variable and non-comparable 25(OH)D levels also impede epidemiological research, e.g. the development and establishment of evidence-based reference values for the evaluation of vitamin $\mathrm{D}$ status, especially deficiency and sufficiency, is challenging [45].

For instance, data sources which have been used to derive reference values for Vitamin $\mathrm{D}$ deficiency are also largely based on unstandardized 25(OH)D measurements. The consequences of this are not totally clear and this derivation process should be revised [45]. Moreover, valid quantification of vitamin $\mathrm{D}$ deficiency in (nationally representative) populations is required to develop dietary reference values as well as to evaluate the need for evidence-based public health strategies e.g. food fortification $[16,23]$. 
The current results show that, depending on the laboratory method, the estimation of population quantities at risk of deficiency and insufficiency may differ substantially which should be considered while implementing prevention measures. Accurate quantification of the magnitude of the public health problem is a critical piece of data upon which national health policy relies. It has been suggested that from a public health perspective, a prevalence of micronutrient deficiency at a rate greater than $20 \%$ in the entire population and/or in subsets of the population considered especially at risk (e.g., infants, children and pregnant women) constitutes a public health issue that may warrant intervention [47]. This is of consequence in the present work where the estimate of vitamin D deficiency was $>20 \%$ in all three German surveys before standardization, but all fell below $20 \%$ following standardization.

However, a previous publication of the ODIN (Food-based solutions for optimal vitamin D nutrition and health through the life cycle) project included sensitivity analyses on the impact of the standardization on estimates of the association between vitamin $\mathrm{D}$ and all-cause mortality as a major adverse outcome measure [48]. For the mortality risk estimates of pooled data analyses that included data from our surveys, the work reported that no major differences between original and standardized 25(OH)D concentrations were observed, but a few percent of the participants, which is relevant from a public health perspective, were indeed re-classified into different $25(\mathrm{OH}) \mathrm{D}$ groups after the standardization procedure. Estimates for the DEGS1 data in particular became slightly lower after standardization but did not differ significantly from results using original data. In general, the standardization had an important impact on classification of subgroups, but it has not a large impact on individual risk estimation.

\section{Conclusions}

The use of standardization of 25(OH)D levels has a substantial impact on estimates of the vitamin D status in Germany. Clinical diagnostic and therapeutic as well as public health decision-making require valid and comparable data. Therefore, standardization and calibration of commercial, clinical and research laboratory assays for 25(OH)D measurement should become common practice. Although the VDSP made substantial progress to overcome the mentioned problems in the past few years, there is still some way to go. Until then, laboratory technicians, physicians, researchers, and authorities must be aware of limitations when comparing and interpreting vitamin D values especially those derived from different assays and laboratories.

Disclaimer: The findings and conclusions in this report are those of the authors and do not necessarily represent the views of the National Institutes of Health or the US Department of Health and Human Services.

\section{Abbreviations}

25(OH)D: Serum 25-hydroxyvitamin D; CDC: Centers for Disease Control and Prevention; CLIA: Chemiluminescent immunoassay; DEGS1: German Health Interview and Examination Survey for Adults; GNHIES98: German National Health Interview and Examination Survey 1998; HPLC: High performance liquid chromatography; IOM: Institute of Medicine, USA; KiGGS: German Health Interview and Examination Survey for Children and Adolescents; LC MS/MS: Liquid chromatography-tandem mass spectrometry; NIST: National Institute for Standards and Technology; ODIN: Food-based solutions for optimal vitamin D nutrition and health through the life cycle; RMP: Reference Measurement Procedures; VDSP: Vitamin D Standardization Program

\section{Funding}

The DEGS study was funded by the German Federal Ministry of Health and the Federal Ministry of Education and Research. GNHIES98 was funded by the German Federal Ministry of Health. The KiGGS study was funded by the German Federal Ministry of Health, the Ministry of Education and Research and the Federal Ministry of Food, Agriculture and Consumer Protection. The funders had no role in study design, data collection and analysis, interpretation of data, decision to publish, or preparation/writing of the manuscript.

\section{Availability of data and materials}

The datasets generated and/or analysed during the current study cannot be made publicly available because informed consent from study participants did not cover public deposition of data. However, the minimal data set underlying the findings is archived in the Health Monitoring Research Data Centre at the Robert Koch Institute (RKI) and can be accessed by all interested researchers (as public use file on request). On-site access to the data set is possible at the Secure Data Center of the RKI's Health Monitoring Research Data Centre.

Requests should be submitted to the Health Monitoring Research Data Centre, Robert Koch Institute, Berlin, Germany (e-mail: fdz@rki.de).

\section{Authors' contributions}

GBMM, CSN, MAB, MT, CTS, KDC and RADA conceived and participated in the design of the study. MR, CTS, KDC and RADA analyzed the data. GBMM, KDC, CTS, CSN, MAB, MT, NR, RADA, KGD and ZS made substantial contribution to interpretation and/or acquisition of data. MR wrote the original draft. GBMM, KDC, CTS, CSN, MAB, MT, NR, RADA, KGD and ZS revised the manuscript. All authors read and approved the final manuscript.

\section{Ethics approval and consent to participate}

GNHIES98, DEGS1 and KiGGS were conducted in accordance with the Declaration of Helsinki and the study protocols of each survey were approved by the Federal and State Commissioners for Data Protection. The protocols of KiGGS and DEGS1 were also approved by the ethics committee of the Charité - Universitätsmedizin Berlin. Participants beyond 14 years of age of each study and all parents of children who participated in KiGGS provided written informed consent before the study procedures.

Consent for publication

Not applicable.

\section{Competing interests}

The authors declare that they have no competing interests.

\section{Publisher's Note}

Springer Nature remains neutral with regard to jurisdictional claims in published maps and institutional affiliations.

\section{Author details}

'Department of Epidemiology and Health Monitoring, Robert Koch Institute, General-Pape-Straße 62-66, 12101 Berlin, Germany. ${ }^{2}$ Institute of Public Health, Charité-Universitätsmedizin, Seestraße 73, 13347 Berlin, Germany.

${ }^{3}$ Department of Public Health Sciences, Stritch School of Medicine, Loyola University Chicago, Maywood, IL 60153, USA. ${ }^{4}$ Cork Centre for Vitamin D and Nutrition Research, School of Food and Nutritional Sciences, University College Cork, College Road, Cork T12 K8AF, Ireland. ${ }^{5}$ Vitamin D Standardization Program (VDSP), 520 Ferdinand Dr, Havre de Grace, MD 21078, USA. 
Received: 4 February 2018 Accepted: 27 June 2018 Published online: 06 July 2018

\section{References}

1. Holick MF. Vitamin D deficiency. N Engl J Med. 2007;357:266-81. https://doi. org/10.1056/NEJMra070553.

2. Holick MF. Sunlight and vitamin D for bone health and prevention of autoimmune diseases, cancers, and cardiovascular disease. Am J Clin Nutr. 2004;80:1678S-88S. https://www.ncbi.nlm.nih.gov/pubmed/15585788

3. Institute of Medicine. Dietary reference intakes for calcium and vitamin D. Washington, D.C.: The National Academies Press; 2011.

4. Holick MF, Binkley NC, Bischoff-Ferrari HA, Gordon CM, Hanley DA, Heaney $\mathrm{RP}$, et al. Evaluation, treatment, and prevention of vitamin D deficiency: an Endocrine Society clinical practice guideline. J Clin Endocrinol Metab. 2011; 96:1911-30. https://doi.org/10.1210/jc.2011-0385.

5. Scientific Advisory Committee on Nutrition Vitamin D and Health 2016. Available from: https://www.gov.uk/government/publications/sacn-vitamind-and-health-report Accessed 27 Jan 2018.

6. Parker J, Hashmi O, Dutton D, Mavrodaris A, Stranges S, Kandala NB, et al. Levels of vitamin D and cardiometabolic disorders: systematic review and meta-analysis. Maturitas. 2010;65:225-36. https://doi.org/10.1016/j. maturitas.2009.12.013.

7. Jenab M, Bueno-de-Mesquita HB, Ferrari P, van Duijnhoven FJ, Norat T, Pischon $T$, et al. Association between pre-diagnostic circulating vitamin $\mathrm{D}$ concentration and risk of colorectal cancer in European populations:a nested case-control study. BMJ. 2010;340:b5500. https:// doi.org/10.1136/bmj.b5500.

8. Holick MF. Vitamin D status: measurement, interpretation, and clinical application. Ann Epidemiol. 2009;19:73-8. https://doi.org/10.1016/j. annepidem.2007.12.001.

9. Tai SS, Bedner M, Phinney KW. Development of a candidate reference measurement procedure for the determination of 25-hydroxyvitamin D3 and 25-hydroxyvitamin D2 in human serum using isotope-dilution liquid chromatography-tandem mass spectrometry. Anal Chem. 2010;82:1942-8. https://doi.org/10.1021/ac9026862.

10. Wallace AM, Gibson S, de la Hunty A, Lamberg-Allardt C, Ashwell M. Measurement of 25-hydroxyvitamin D in the clinical laboratory: current procedures, performance characteristics and limitations. Steroids. 2010;75: 477-88. https://doi.org/10.1016/j.steroids.2010.02.012.

11. Binkley $N$, Sempos CT, Vitamin DSP. Standardizing vitamin D assays: the way forward. J Bone Miner Res. 2014;29:1709-14. https://doi.org/ 10.1002/jbmr.2252.

12. Snellman G, Melhus H, Gedeborg R, Byberg L, Berglund L, Wernroth L, et al. Determining vitamin D status: a comparison between commercially available assays. PLoS One. 2010;5:e11555. https://doi.org/ 10.1371/journal.pone.0011555.

13. Binkley N, Krueger D, Cowgill CS, Plum L, Lake E, Hansen KE, et al. Assay variation confounds the diagnosis of hypovitaminosis D: a call for standardization. J Clin Endocrinol Metab. 2004;89:3152-7. https://doi.org/ 10.1210/jc.2003-031979.

14. Carter GD, Carter R, Jones J, Berry J. How accurate are assays for 25hydroxyvitamin $\mathrm{D}$ ? Data from the international vitamin $\mathrm{D}$ external quality assessment scheme. Clin Chem. 2004;50:2195-7. https://doi.org/ 10.1373/clinchem.2004.040683.

15. Sempos CT, Vesper HW, Phinney KW, Thienpont LM, Coates PM, Vitamin DSP. Vitamin D status as an international issue: national surveys and the problem of standardization. Scand J Clin Lab Invest Suppl. 2012;243:32-40. https://www.ncbi.nlm.nih.gov/pubmed/22536760.

16. Cashman KD, Kiely M, Kinsella M, Durazo-Arvizu RA, Tian L, Zhang Y, et al. Evaluation of vitamin D standardization program protocols for standardizing serum 25-hydroxyvitamin D data: a case study of the program's potential for national nutrition and health surveys. Am J Clin Nutr. 2013;97:1235-42. https://doi.org/10.3945/ajcn.112.057182.

17. Sarafin K, Durazo-Arvizu R, Tian L, Phinney KW, Tai S, Camara JE, et al. Standardizing 25-hydroxyvitamin D values from the Canadian health measures survey. Am J Clin Nutr. 2015;102:1044-50. https://doi.org/10. 3945/ajcn.114.103689.

18. Schleicher RL, Sternberg MR, Looker AC, Yetley EA, Lacher DA, Sempos CT, et al. National Estimates of serum Total 25-Hydroxyvitamin D and metabolite concentrations measured by liquid chromatography-tandem mass spectrometry in the US population during 2007-2010. J Nutr. 2016;146: 1051-61. https://doi.org/10.3945/jn.115.227728.

19. Cashman KD, Dowling KG, Skrabakova Z, Kiely M, Lamberg-Allardt C, Durazo-Arvizu RA, et al. Standardizing serum 25-hydroxyvitamin D data from four Nordic population samples using the vitamin D standardization program protocols: shedding new light on vitamin D status in Nordic individuals. Scand J Clin Lab Invest. 2015;75:549-61. https://doi.org/10.3109/ 00365513.2015 .1057898 .

20. Hintzpeter B, Mensink GB, Thierfelder W, Muller MJ, Scheidt-Nave C. Vitamin D status and health correlates among German adults. Eur J Clin Nutr. 2008; 62:1079-89. https://doi.org/10.1038/sj.ejcn.1602825.

21. Hintzpeter B, Scheidt-Nave C, Muller MJ, Schenk L, Mensink GB. Higher prevalence of vitamin $\mathrm{D}$ deficiency is associated with immigrant background among children and adolescents in Germany. J Nutr. 2008;138: 1482-90. http://www.ncbi.nlm.nih.gov/pubmed/18641195

22. Rabenberg M, Scheidt-Nave C, Busch MA, Rieckmann N, Hintzpeter B, Mensink GB. Vitamin D status among adults in Germany - results from the German health interview and examination survey for adults (DEGS1). BMC Public Health. 2015;15:641. https://doi.org/10.1186/s12889-015-2016-7.

23. Cashman KD, Dowling KG, Skrabakova Z, Gonzalez-Gross M, Valtuena J, De Henauw S, et al. Vitamin D deficiency in Europe: pandemic? Am J Clin Nutr. 2016;103:1033-44. https://doi.org/10.3945/ajen.115.120873.

24. Bellach BM, Knopf H, Thefeld W. Der Bundes-Gesundheitssurvey. 1997/ 98. Gesundheitswesen. 1998;60(Suppl 2):S59-68. http://www.ncbi.nlm.nih gov/pubmed/10063725

25. Thefeld W, Stolzenberg H, Bellach BM. Bundes-Gesundheitssurvey: Response, Zusammensetzung der Teilnehmer und Non-ResponderAnalyse. Gesundheitswesen. 1999;61:Spec No:S57-61. http://www.ncbi. nlm.nih.gov/pubmed/10726397.

26. Mensink GB, Beitz R. Food and nutrient intake in east and West Germany, 8 years after the reunification-the German nutrition survey 1998. Eur J Clin Nutr. 2004;58:1000-10. https://doi.org/10.1038/sj.ejcn.1601923.

27. Kamtsiuris P, Lange M, Hoffmann R, Schaffrath Rosario A, Dahm S, Kuhnert R, et al. The first wave of the German health interview and examination survey for adults (DEGS1): sample design, response, weighting and representativeness. Bundesgesundheitsblatt Gesundheitsforschung Gesundheitsschutz. 2013;56: 620-30. https://doi.org/10.1007/s00103-012-1650-9.

28. Scheidt-Nave C, Kamtsiuris P, Gosswald A, Holling H, Lange M, Busch MA, et al. German health interview and examination survey for adults (DEGS) design, objectives and implementation of the first data collection wave. BMC Public Health. 2012;12:730. https://doi.org/10.1186/1471-2458-12-730.

29. Kurth BM, Kamtsiuris P, Holling H, Schlaud M, Dolle R, Ellert U, et al. The challenge of comprehensively mapping children's health in a nation-wide health survey: design of the German KiGGS-study. BMC Public Health. 2008; 8:196. https://doi.org/10.1186/1471-2458-8-196.

30. Kamtsiuris P, Lange M, Schaffrath Rosario A. Der Kinder- und Jugendgesundheitssurvey (KiGGS): Stichprobendesign, Response und Nonresponse-Analyse. Bundesgesundheitsblatt Gesundheitsforschung Gesundheitsschutz. 2007;50:547-56. https://doi.org/10.1007/s00103-007-0215-9.

31. Tian L, Durazo-Arvizu RA, Myers G, Brooks S, Sarafin K, Sempos $\subset T$. The estimation of calibration equations for variables with heteroscedastic measurement errors. Stat Med. 2014;33:4420-36. https://doi.org/10.1002/sim.6235.

32. Stepman HC, Vanderroost A, Van Uytfanghe K, Thienpont LM. Candidate reference measurement procedures for serum 25-hydroxyvitamin D3 and 25-hydroxyvitamin D2 by using isotope-dilution liquid chromatographytandem mass spectrometry. Clin Chem. 2011;57:441-8. https://doi.org/10. 1373/clinchem.2010.152553.

33. Mineva EM, Schleicher RL, Chaudhary-Webb M, Maw KL, Botelho JC, Vesper HW, et al. A candidate reference measurement procedure for quantifying serum concentrations of 25-hydroxyvitamin D(3) and 25-hydroxyvitamin D(2) using isotope-dilution liquid chromatography-tandem mass spectrometry. Anal Bioanal Chem. 2015;407:5615-24. https://doi.org/10.1007/s00216-015-8733-z

34. Joint Committee for Traceability in Laboratory Medicine database. Laboratory medicine and in-vitro diagnostics 2016. Available from: http:// www.bipm.org/jctlm/home.do Accessed 27 Jan 2018.

35. Centers for Disease Control and Prevention. Laboratory Quality Assurance and Standardization Programs 2016. Available from: https://www.cdc.gov/ labstandards/hs.html Accessed 27 Jan 2018.

36. Lehmann B. Zur Physiologie von Vitamin D. In: Reichrath J, Lehmann B, Spitz J, editors. Vitamin D - Update 2012. Oberhaching: Dustri-Verlag Dr. Karl Feistle; 2012 
37. Yetley EA, Pfeiffer CM, Schleicher RL, Phinney KW, Lacher DA, Christakos S, et al. NHANES monitoring of serum 25-hydroxyvitamin D: a roundtable summary. J Nutr. 2010;140:2030S-45S. https://doi.org/10.3945/jn.110.121483.

38. Carter GD. 25-hydroxyvitamin D: a difficult analyte. Clin Chem. 2012;58:486-8. https:/doi.org/10.1373/dinchem.2011.180562.

39. Agborsangaya C, Toriola AT, Grankvist K, Surcel HM, Holl K, Parkkila S, et al. The effects of storage time and sampling season on the stability of serum 25-hydroxy vitamin D and androstenedione. Nutr Cancer. 2010;62:51-7. https://doi.org/10.1080/01635580903191460.

40. Ocke MC, Schrijver J, Obermann-de Boer GL, Bloemberg BP, Haenen GR, Kromhout D. Stability of blood (pro)vitamins during four years of storage at -20 degrees C: consequences for epidemiologic research. J Clin Epidemiol. 1995;48:1077-85. http://www.ncbi.n/m.nih.gov/pubmed/7775995

41. Ersfeld DL, Rao DS, Body JJ, Sackrison JL Jr, Miller AB, Parikh N, et al. Analytical and clinical validation of the $25 \mathrm{OH}$ vitamin $\mathrm{D}$ assay for the LIAISON automated analyzer. Clin Biochem. 2004;37:867-74. https://doi.org/ 10.1016/j.clinbiochem.2004.06.006.

42. Schleicher RL, Sternberg MR, Lacher DA, Sempos CT, Looker AC, DurazoArvizu RA, et al. The vitamin D status of the US population from 1988 to 2010 using standardized serum concentrations of 25-hydroxyvitamin D shows recent modest increases. Am J Clin Nutr. 2016;104:454-61. https:// doi.org/10.3945/ajcn.115.127985.

43. Farrell CJ, Martin S, MCWhinney B, Straub I, Williams P, Herrmann M. Stateof-the-art vitamin $D$ assays: a comparison of automated immunoassays with liquid chromatography-tandem mass spectrometry methods. Clin Chem. 2012;58:531-42. https://doi.org/10.1373/clinchem.2011.172155.

44. Antoniucci DM, Black DM, Sellmeyer DE. Serum 25-hydroxyvitamin D is unaffected by multiple freeze-thaw cycles. Clin Chem. 2005;51:258-61. https://doi.org/10.1373/clinchem.2004.041954.

45. Sempos CT, Durazo-Arvizu RA, Binkley N, Jones J, Merkel JM, Carter GD. Developing vitamin $\mathrm{D}$ dietary guidelines and the lack of 25 -hydroxyvitamin $D$ assay standardization: the ever-present past. J Steroid Biochem Mol Biol. 2015; https://doi.org/10.1016/j.jsbmb.2015.08.027.

46. Manson JE, Brannon PM, Rosen CJ, Taylor CL. Vitamin D deficiency - is there really a pandemic? N Engl J Med. 2016;375:1817-20. https://doi. org/10.1056/NEJMp1608005.

47. Cashman KD, Sheehy T, O'Neill CM. Is vitamin D deficiency a public health concern for low middle income countries? A systematic literature review. Eur J Nutr. 2018; https://doi.org/10.1007/s00394-018-1607-3.

48. Gaksch M, Jorde R, Grimnes G, Joakimsen R, Schirmer H, Wilsgaard T, et al. Vitamin $\mathrm{D}$ and mortality: individual participant data meta-analysis of standardized 25-hydroxyvitamin D in 26916 individuals from a European consortium. PLoS One. 2017;12:e0170791. https://doi.org/10. 1371/journal.pone.0170791.

\section{Ready to submit your research? Choose BMC and benefit from:}

- fast, convenient online submission

- thorough peer review by experienced researchers in your field

- rapid publication on acceptance

- support for research data, including large and complex data types

- gold Open Access which fosters wider collaboration and increased citations - maximum visibility for your research: over $100 \mathrm{M}$ website views per year

At BMC, research is always in progress.

Learn more biomedcentral.com/submissions 